\title{
Results of Four-Year Rectal Vancomycin-Resistant Enterococci Surveillance in a Pediatric Hematology-Oncology Ward: From Colonization to Infection
}

\author{
Bir Pediatrik Hematoloji-Onkoloji Ünitesinde Vankomisine Dirençli Enterokok Kolonizasyon \\ ve Enfeksiyonu: Dört Yıllık Sürveyans Sonuçları
}

\begin{abstract}
Hacer Aktürk1, Murat Sütçü1, Ayper Somer¹, Serap Karaman², Manolya Acar¹, Ayşegül Ünüvar², Sema Anak², Zeynep Karakaş², Aslı Özdemir ${ }^{3}$, Kutay Sarsar, Derya Aydın, Nuran Salman ${ }^{1}$

1 istanbul University istanbul Faculty of Medicine, Department of Pediatric Infectious Diseases, Istanbul, Turkey 2 istanbul University istanbul Faculty of Medicine, Department of Pediatric Hematology and Oncology, Istanbul, Turkey

3 istanbul University Istanbul Faculty of Medicine, Infection Control Committee, istanbul, Turkey

4 istanbul University istanbul Faculty of Medicine, Department of Clinical Microbiology, Istanbul, Turkey
\end{abstract}

\section{Abstract}

Objective: To investigate the clinical impact of vancomycinresistant enterococci (VRE) colonization in patients with hematologic malignancies and associated risk factors.

Materials and Methods: Patients colonized and infected with VRE were identified from an institutional surveillance database between January 2010 and December 2013. A retrospective case-control study was performed to identify the risk factors associated with development of VRE infection in VRE-colonized patients.

Results: Fecal VRE colonization was documented in 72 of 229 children (31.4\%). Seven VRE-colonized patients developed subsequent systemic VRE infection (9.7\%). Types of VRE infections included bacteremia $(n=5)$, urinary tract infection $(n=1)$, and meningitis $(n=1)$. Enterococcus faecium was isolated in all VRE infections. Multivariate analysis revealed severe neutropenia and previous bacteremia with another pathogen as independent risk factors for VRE infection development in colonized patients [odds ratio (OR): 35.4, confidence interval $(\mathrm{Cl})$ : 1.7-72.3, $\mathrm{p}=0.02$ and OR: 20.6, $\mathrm{Cl}$ : 1.3-48.6, $\mathrm{p}=0.03$, respectively]. No deaths attributable to VRE occurred.

Conclusion: VRE colonization has important consequences in pediatric cancer patients.

Keywords: Colonization, Infection, Pediatric malignancy, Vancomycinresistant enterococci

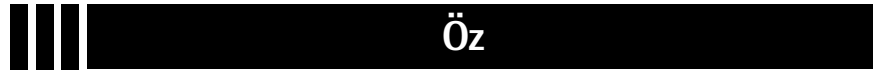

Amaç: Hematolojik malignitesi olan pediatrik hastalarda vankomisine dirençli enterokok (VDE) kolonizasyonunun klinik öneminin araştırılması ve eşlik eden risk faktörlerinin değerlendirilmesi amaçlanmıştır.

Gereç ve Yöntemler: Ocak 2010-Aralık 2013 tarihleri arasında yapılan VDE sürveyans kayıtlarından faydalanılarak VRE ile kolonize ve/veya enfekte olmuş hastalar belirlenmiştir. VDE ile kolonize hastalarda VRE enfeksiyonu gelişimi ile ilişkili risk faktörlerini belirlemek amacıyla retrospektif olgu-kontrol çalışması yapılmıştır.

Bulgular: Çalışma süresince yatırılan 229 hastanın 72'sinde $(\% 31,4)$ rektal VRE kolonizasyonu saptanmıştır. VRE kolonize hastaların yedisinde $(\% 9,7)$ kolonizasyon sonrası sistemik VRE enfeksiyonu gelişmiştir. Beş hastada bakteriyemi $(n=5)$, bir hastada idrar yolu enfeksiyonu $(n=1)$ ve bir hastada menenjit $(n=1)$ gözlenmiştir. Tüm enfeksiyonlarda ilgili klinik örneklerde Enterococcus faecium üretilmiştir. Multivaryant analiz sonucunda, ciddi nötropeni ve başka bir patojene bağlı bakteriyemi öyküsü VDE kolonize hastalarda VDE enfeksiyonu gelişimi için risk faktörleri olarak bulunmuştur [odds ratio $(O R)$ : 35,4 ; güven aralığı $(G A): 1,7-72,3 ; p=0,02$ ve $O R$ : 20,6 ; GA: $1,3-48,6 ; p=0,03$; sırasıyla]. VDE enfeksiyonuna bağlı mortalite saptanmamıştır.

Sonuç: Pediatrik kanser hastalarında VDE kolonizasyonunun önemli klinik sonuçları olduğu gözlenmiştir.

Anahtar Sözcükler: Kolonizasyon, Enfeksiyon, Pediatrik malignite, Vankomisine dirençli enterokok 


\section{Introduction}

Children with cancer are at high risk of developing systemic infections by the microorganisms that colonize their own intestinal system $[1,2]$. Vancomycin-resistant enterococci (VRE) are health care-associated opportunistic pathogens. Limited data exist on the incidence of subsequent VRE infection development among VRE-colonized pediatric cancer patients and associated risk factors, which were investigated in this study.

\section{Materials and Methods}

All patients admitted to the pediatric hematology/oncology ward were sampled within 48-72 $\mathrm{h}$ after admission and weekly thereafter as part of institutional rectal VRE surveillance. An infection control nurse assigned by the Hospital Infection Control Committee (HICC) prospectively tracked the results of rectal surveillance and all health care-associated infections occurring in the hematology/oncology ward. VRE-colonized and VRE-infected patients were identified from the HICC surveillance database retrospectively. Detailed clinical and laboratory features of these patients were collected from their medical records. The overall rate of VRE colonization and the subsequent infection occurrence throughout the study period were determined. To identify the risk factors associated with VRE infection occurrence in a colonized patient, a retrospective case-control study was performed. Patients were defined as VRE- colonized (VRE-C) when the culture of the rectal swab yielded VRE in the absence of any clinical specimens positive for VRE [3]. Systemic VRE infection (VRE-I) was defined as isolation of VRE from a clinical specimen together with signs and symptoms of infection. Statistical analysis was performed with SPSS 21.0 for Windows. Parameters were compared between groups with the chi-square test, Fisher exact test, or Mann-Whitney U test. Variables with a $p$-value of $\leq 0.1$ in univariate analysis were fitted to perform logistic regression analysis to identify independent risk factors associated with VRE infection occurrence.

\section{Results}

A total of 229 children were admitted to the hematology/ oncology ward. Fecal VRE-C was documented in 72 of these patients (31.4\%). Excluding eight patients who were transferred from the pediatric intensive care unit, $89 \%$ of the patients were colonized during their stay in the hematology/oncology ward. Species determination could be performed in 32 VRE-colonized patients: Enterococcus faecium was isolated in 28 patients, Enterococcus gallinarum in 2 patients, and nontypeable Enterococcus in 2 patients.

VRE-I was detected in 7 patients, all of whom were previously colonized with VRE. The overall rate of VRE-I developing in patients with VRE-C was 9.7\%. VRE bacteremia was detected in five patients $(6.9 \%)$. Other VRE infections were urinary

Table 1. Demographic and clinical characteristics of vancomycin-resistant enterococci-colonized patients who developed systemic vancomycin-resistant enterococci infection and those who did not.

\begin{tabular}{|c|c|c|c|}
\hline & $\begin{array}{l}\text { VRE-Colonized Patients } \\
\text { Who Did Not Develop VRE } \\
\text { Infection } \\
(n=65)\end{array}$ & $\begin{array}{l}\text { VRE-Colonized Patients Who } \\
\text { Developed VRE Infection } \\
(n=7)\end{array}$ & p \\
\hline Age, months; mean \pm SD & $77.7 \pm 6.1$ & $45.2 \pm 12.9$ & 0.16 \\
\hline $\begin{array}{l}\text { Sex, } \mathrm{n}(\%) \\
\text { Male } \\
\text { Female }\end{array}$ & $\begin{array}{l}38(58.5) \\
27(41.5)\end{array}$ & $\begin{array}{l}2(28.6) \\
5(71.4)\end{array}$ & 0.13 \\
\hline $\begin{array}{l}\text { Underlying malignancy, } \mathrm{n}(\%) \\
\text { ALL } \\
\text { AML } \\
\text { Solid tumor }\end{array}$ & $\begin{array}{l}33(50.8) \\
15(23.1) \\
17(26.2)\end{array}$ & $\begin{array}{l}2(28.6) \\
3(42.9) \\
2(28.6)\end{array}$ & 0.67 \\
\hline $\begin{array}{l}\text { Duration of time between admission and determination of VRE } \\
\text { colonization, days; mean } \pm \text { SD }\end{array}$ & $27.8 \pm 3.9$ & $25.5 \pm 7.5$ & 0.85 \\
\hline Severe neutropenia $\left(<100 / \mathrm{mm}^{3}\right)$, n (\%) & $11(16.9)$ & $5(71.4)$ & $<0.001$ \\
\hline Previous bacteremia with another pathogen, $\mathrm{n}(\%)$ & $16(24.6)$ & $6(85.7)$ & 0.001 \\
\hline Previous PICU admission, n (\%) & $12(18.5)$ & $3(42.9)$ & 0.15 \\
\hline $\begin{array}{l}\text { Invasive procedures, n (\%) } \\
\text { CVC/port } \\
\text { Surgery } \\
\text { TPN }\end{array}$ & $\begin{array}{l}62(95.4) \\
34(35.1) \\
26(40)\end{array}$ & $\begin{array}{l}7(100) \\
6(54.5) \\
6(85.7)\end{array}$ & $\begin{array}{l}0.56 \\
0.20 \\
0.02\end{array}$ \\
\hline
\end{tabular}


tract infection in one patient and meningitis in one patient. Enterococcus faecium was isolated in all patients with VRE-I. The mean duration of time from identification of VRE colonization to development of a VRE infection was $32.4 \pm 8.6$ days (median: 25 days, range: 10-73 days).

Univariate analysis of demographic and clinical variables associated with development of VRE-I among patients with VRE-C is presented in Table 1. Duration of neutropenia was significantly longer in patients with VRE-I than in patients with VRE-C (12.8 \pm 1.4 days vs. $38.5 \pm 7.3$ days; $p=0.016)$. Similarly, total parenteral nutritional support was found to be received for a longer time by patients with VRE-I (9.37 \pm 0.8 days vs. $15.33 \pm 5.5$ days; $p=0.04)$. Antimicrobials used among patients are shown in Table 2. Four out of seven patients were receiving a glycopeptide antibiotic when a systemic VRE infection was diagnosed. Multivariate analysis revealed severe neutropenia and history of previous bacteremia with another pathogen as independent risk factors for development of VRE infection in a VRE-colonized patient with cancer (Table 3).

All VRE infections were treated with linezolid. No VREattributable deaths occurred during systemic VRE infections. However, crude mortality was higher in patients who suffered from VRE infection than those who did not (2/7 (28.6\%) vs. 4/65 (6.2\%), respectively; $p=0.04)$.

\section{Discussion}

Overall, 31.4\% of patients admitted to our hematology/oncology ward were colonized with VRE. Colonization rates in other studies ranged from $4.7 \%$ to $38 \%[4,5,6,7]$. Systemic VRE infections develop mostly in VRE-colonized patients [8,9], although some contrary cases may exist rarely $[5,10]$. In this study, about 1 in 10 VRE-colonized patients developed subsequent systemic VRE infection (9.7\%). Studies evaluating cancer patients reported a range of $13 \%$ to $61 \%$ rate of progression of VRE colonization to VRE bacteremia $[6,10,11,12,13]$.

Results of univariate analysis revealed some risk factors associated with VRE-I development. One of them was severe neutropenia $\left(<100 / \mathrm{mm}^{3}\right)$ and longer duration of neutropenia, which was consistent with the literature $[4,7,12,13]$. The presence and a longer duration of total parenteral nutritional support were more likely to be present in VRE-I patients. It increases the risk of infection due to the use of an invasive central line, tendency for a longer hospitalization, and disadvantageous effects on gastrointestinal flora $[14,15]$. Its association with VRE infection in our univariate analysis may merely indicate illness severity of the patients, which is the main predisposing factor for VRE bacteremia $[10,16]$. In casecontrol studies, colonization and infection with VRE have been associated with exposure to several antibiotics, especially to glycopeptides $[8,17]$. In the current study, VRE-I patients had longer duration of glycopeptide treatment and more frequently received glycopeptides after detection of VRE colonization, similar to literature findings $[7,10,13]$. After multivariate analysis, severe neutropenia and history of previous bacteremia with another pathogen remained as independent risk factors for development of VRE infection in a colonized patient. Previous bacteremia episodes were not evaluated in similar reports. It may be proposed that a previous blood stream infection history indicates the patient's severity of illness, which in turn increases the risk of a VRE infection. Moreover, a bacteremia episode itself might have caused clinical deterioration of the patients, predisposing them to the progression of VRE colonization to a systemic infection.

It was reported that active screening leads to reduced VRE colonization, infection, and reduced costs [18]. In a comparative

\begin{tabular}{|c|c|c|c|}
\hline & $\begin{array}{l}\text { VRE-Colonized Patients } \\
\text { Who Did Not Develop VRE } \\
\text { Infection } \\
(n=65)\end{array}$ & $\begin{array}{l}\text { VRE-Colonized } \\
\text { Patients Who } \\
\text { Developed VRE } \\
\text { Infection } \\
(n=7)\end{array}$ & $\mathbf{p}$ \\
\hline Number of antibiotics administered within last 3 weeks, mean \pm SD & $2.9 \pm 0.1$ & $3.4 \pm 0.2$ & 0.23 \\
\hline \multicolumn{4}{|l|}{ Antimicrobial treatment, n (\%) } \\
\hline Carbapenems & $38(58.5)$ & $6(85.7)$ & 0.16 \\
\hline Glycopeptides & $43(66.2)$ & $7(100)$ & 0.06 \\
\hline Aminoglycosides & $49(75.4)$ & $5(71.4)$ & 0.81 \\
\hline Amphotericin B & $11(16.9)$ & $4(57.1)$ & 0.03 \\
\hline
\end{tabular}




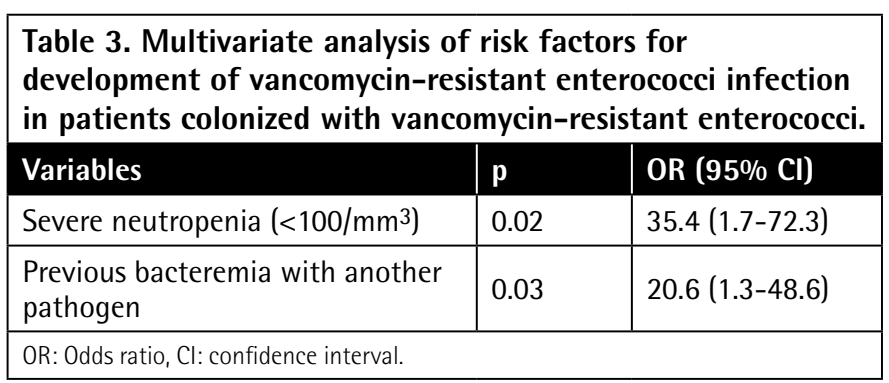

study, the rate of VRE infection was found to be lower in a hospital with active screening [19]. It increases awareness of the staff and leads to improvement in compliance with control measures. Thus, by detecting all carriers, onward transmission of colonization may be prevented and resultant VRE infections may be reduced. Our study revealed a remarkable incidence of VRE colonization and subsequent progression to infection, indicating the ongoing clinical importance of VRE in this high-risk population.

\section{Conclusion}

This study provides the four-year incidence of VRE colonization and its clinical impact on pediatric malignancy patients. Furthermore, it evaluates risk factors for progression from colonization to infection, which may help physicians to identify VRE-colonized patients at high risk of developing systemic infection.

\section{Ethics}

Ethics Committee Approval: The study protocol was approved by Ethics Committee of İstanbul University, İstanbul Medical Faculty; Informed Consent: Not required.

\section{Authorship Contributions}

Surgical and Medical Practices: Hacer Aktürk, Murat Sütçü, Ayper Somer, Serap Karaman, Manolya Acar, Ayşegül Ünüvar, Sema Anak, Zeynep Karakaş, Aslı Özdemir, Kutay Sarsar, Derya Aydın, Nuran Salman; Concept: Hacer Aktürk, Murat Sütçü; Design: Hacer Aktürk, Murat Sütçü; Data Collection or Processing: Hacer Aktürk, Murat Sütçü, Ayper Somer, Serap Karaman, Manolya Acar, Ayşegül Ünüvar, Sema Anak, Zeynep Karakaş, Asıı̈ Özdemir, Kutay Sarsar, Derya Aydın, Nuran Salman; Analysis or Interpretation: Hacer Aktürk, Murat Sütçü, Serap Karaman, Ayper Somer, Nuran Salman; Literature Search: Hacer Aktürk, Murat Sütçü, Ayper Somer, Serap Karaman, Manolya Acar, Ayşegül Ünüvar, Sema Anak, Zeynep Karakaş, Aslı Özdemir, Kutay Sarsar, Derya Aydın, Nuran Salman; Writing: Hacer Aktürk.

Conflict of Interest: The authors of this paper have no conflicts of interest, including specific financial interests, relationships, and/ or affiliations relevant to the subject matter or materials included.

\section{References}

1. Schimpff SC, Young VM, Greene WH, Vermeulen GD, Moody MR, Wiernik PH. Origin of infection in acute nonlymphocytic leukemia: significance of hospital acquisition of potential pathogens. Ann Intern Med 1972;77:707-714.

2. Fainstein V, Rodriguez V, Turck M, Hermann G, Rosenbaum B, Bodey GP. Patterns of oropharyngeal and fecal flora in patients with acute leukemia. J Infect Dis 1981;144:10-18.

3. Olivier CN, Blake RK, Steed LL, Salgado CD. Risk of vancomycin-resistant Enterococcus (VRE) bloodstream infection among patients colonized with VRE. Infect Control HospEpidemiol 2008;29:404-409.

4. Ford CD, Lopansri BK, Haydoura S, Snow G, Dascomb KK, Asch J, Bo Petersen F, Burke JP. Frequency, risk factors, and outcomes of vancomycin-resistant Enterococcus colonization and infection in patients with newly diagnosed acute leukemia: different patterns in patients with acute myelogenous and acute lymphoblastic leukemia. Infect Control Hosp Epidemiol 2015;36:47-53.

5. Suntharam N, Lankford MG, Trick WE, Peterson LR, Noskin GA. Risk factors for acquisition of vancomycin-resistant enterococci among hematologyoncology patients. Diagn Microbiol Infect Dis 2002;43:183-188.

6. Worth U, Thursky KA, Seymour JF, Slavin MA. Vancomycin-resistant Enterococcus faecium infection in patients with hematologic malignancy: patients with acute myeloid leukemia are at high-risk. Eur J Haematol 2007;79:226-233.

7. Dubberke ER, Hollands JM, Georgantopoulos P, Augustin K, DiPersio JF, Mundy LM, Khoury HJ. Vancomycin-resistant enterococcal bloodstream infections on a hematopoietic stem cell transplant unit: are the sick getting sicker? Bone Marrow Transplant 2006;38:813-819.

8. Zaas AK, Song $X$, Tucker P, Perl TM. Risk factors for development of vancomycin-resistant enterococcal bloodstream infection in patients with cancer who are colonized with vancomycin-resistant enterococci. Clin Infect Dis 2002;35:1139-1146.

9. Kang $Y$, Vicente M, Parsad S, Brielmeier B, Pisano J, Landon E, Pettit NN Evaluation of risk factors for vancomycin-resistant Enterococcus bacteremia among previously colonized hematopoietic stem cell transplant patients. Transpl Infect Dis 2013;15:466-473.

10. Matar MJ, Safdar A, Rolston KV. Relationship of colonization with vancomycin-resistant enterococci and risk of systemic infection in patients with cancer. Clin Infect Dis 2006;42:1506-1507.

11. Matar MJ, Tarrand J, Raad I, Rolston KV. Colonization and infection with vancomycin-resistant enterococcus among patients with cancer. Am J Infect Control 2006;34:534-536.

12. Weinstock DM, Conlon $M$, lovino $C_{\text {, Aubrey }} \mathrm{T}_{\text {, Gudiol }} \mathrm{C}_{\text {, Riedel }}$, Young JW Kiehn TE, Zuccotti G. Colonization, bloodstream infection, and mortality caused by vancomycin-resistant enterococcus early after allogeneic hematopoietic stem cell transplant. Biol Blood Marrow Transplant 2007;13:615-621.

13. Husni $R$, Hachem $R$, Hanna $H$, Raad I. Risk factors for vancomycin-resistant Enterococcus (VRE) infection in colonized patients with cancer. Infect Control Hosp Epidemiol 2002;23:102-103.

14. Guglielmi FW, Boggio-Bertinet D, Federico A, Forte GB, Guglielmi A, Loguercio C, Mazzuoli S, Merli M, Palmo A, Panella C, Pironi L, Francavilla A. Total parenteral nutrition-related gastroenterological complications. Dig Liver Dis 2006;38:623-642.

15. Kuehnert MJ, Jernigan $J A$, Pullen $A L$, Rimland $D$, Jarvis WR. Association between mucositis severity and vancomycin-resistant enterococcal bloodstream infection in hospitalized cancer patients. Infect Control Hosp Epidemiol 1999;20:660-663.

16. Dever LL, China C, Eng RH, O'Donovan C, Johanson WG Jr. Vancomycinresistant Enterococcus faecium in a Veterans Affairs Medical Center: association with antibiotic usage. Am J Infect Control 1998;26:40-46.

17. Tacconelli E, Cataldo MA. Vancomycin-resistant enterococci (VRE): transmission and control. Int J Antimicrob Agents 2008;31:99-106.

18. Humphreys $\mathrm{H}$. Controlling the spread of vancomycin-resistant enterococci. Is active screening worthwhile? J Hosp Infect 2014;88:191-198.

19. Price CS, Paule $S$, Noskin GA, Peterson LR. Active surveillance reduces the incidence of vancomycin-resistant enterococcal bacteremia. Clin Infect Dis 2003;37:921-928. 